\title{
Mapping of Genes Determining Penicillin-resistance and Serum-sensitivity in Salmonella enteritidis
}

\author{
By DOROTHEA E. MYERS, $\dagger$ BRUCE A. D. STOCKER \\ AND ROBERT J. ROANTREE* \\ Department of Medical Microbiology, Stanford University School of Medicine, \\ Stanford, California 94305, U.S.A.
}

(Received 16 October 1979; revised 4 January 1980)

\begin{abstract}
Two presumptive single-step mutants, resistant to penicillin and sensitive to the bactericidal effect of normal human serum, were isolated on penicillin gradient plates from a smooth, penicillin-sensitive, serum-resistant strain of Salmonella enteritidis $(09,12$; gal hisEI cys). The chemical composition of their lipopolysaccharides, their phage-sensitivity patterns, and their serological and cultural properties showed one to be 'part-rough' and the other smooth. Hfr strains with O antigens O4,5,12 or O1,4,5,12 (two Salmonella typhimurium and one $S$. abony) and one $S$. enteritidis $\mathrm{F}^{\prime}, \mathrm{O}$, 12 , were crossed with the $S$. enteritidis $\mathrm{O} 9,12$ mutants. The results with the part-rough mutant indicate that its penicillin-resistance, serum-sensitivity and rough phage pattern result from a single mutation between hisEI and the part of the $r f b$ gene cluster determining $O$ specificity, 4 (abequose) or 9 (tyvelose). Transduction experiments confirmed that the mutation is closely linked to the his operon. This mutation is inferred to cause an incomplete defect in a transferase for galactose, mannose or rhamnose, the smooth sugars common to $04,5,12$ and 09,12 . Results from similar crosses to the smooth, serum-sensitive, penicillin-resistant $S$. enteritidis mutant indicate that its serum-sensitivity is not linked to his. The occasional independent segregation of penicillin-resistance and serum-sensitivity suggests that other loci modify penicillinresistance.
\end{abstract}

\section{INTRODUCTION}

Michael \& Braun (1958) reported that passage of strains of Shigella dysenteriae or Escherichia coli on a series of gradient plates, each with a higher concentration of penicillin than the preceding one, yielded penicillin-resistant mutants which were more easily killed by exposure to normal serum (antibody plus complement) than were the parent strains, but which retained the O-antigenic specificities of the parent strains. Roantree \& Steward (1965) used this method to derive serum-sensitive mutants from serum-resistant, smooth Salmonella enteritidis and Salmonella typhimurium strains, to test whether becoming serum-sensitive reduced virulence. They observed that in a series of mutants, derived stepwise from a given parent strain, only one or a few of the mutations causing increased penicillin-resistance were associated with increased sensitivity to serum. Some serum-sensitive strains were apparently smooth, others were rough, as indicated by colonial morphology and growth with deposit in broth. Nelson \& Roantree (1967) characterized lipopolysaccharides (LPS) from these mutants and from single-step penicillin- or cephalothin-resistant mutants of the same two parent strains. The mutants fell into five groups: $(a)$ hapten-negative rough mutants lacking detectable O-specific material in the LPS and L1 fraction [the supernatant after ultra-

$\uparrow$ Present address: Department of Biochemistry, Case Western Reserve University, Cleveland, Ohio 44106, U.S.A. 
centrifugation in the phenol-water procedure (Westphal et al., 1952) for the extraction of LPS]; $(b)$ a hapten-positive rough mutant with O-specific material in the $\mathrm{L} 1$ fraction only; (c) part-rough mutants, with phenotypes intermediate between smooth and rough; $(d)$ mutants which were serum-sensitive but unaltered in smooth character; $(e)$ penicillinresistant mutants not altered in resistance to serum, in antigenic character or LPS sugar composition, but less virulent (for mice) than the parent strain.

We report here genetic and other investigations of two serum-sensitive mutants of a genetically marked smooth $S$. enteritidis strain, obtained at a single step by selection for resistance to penicillin. One mutant, R146, fell into the part-rough category $c$ described above. The other, R147, possessed the characteristics of category $d$, i.e. serum-sensitive but apparently smooth. Tests of the activity of extracts of R146 (by Dr H. Nikaido) showed that it was not defective in any of the enzymes needed for synthesis of the nucleotide precursors of the components of the repeat unit of group B or D LPS.

\section{METHODS}

Media. The media used were Difco nutrient broth and nutrient agar and, as defined medium, that of Davis $\&$ Mingioli (1950), solidified with purified agar (Difco Noble agar) and with glucose $\left(2 \mathrm{~g}^{-1}\right)$ as energy source; its citrate component was omitted for tests on sugar utilization, etc.

Bacterial strains and phages. The bacterial strains used are listed in Table 1. Salmonella enteritidis strain R134, from which penicillin-resistant mutants were isolated, is a his-1461 cys gal derivative, obtained by three successive mutations, each after exposure to ethyl methanesulphonate, from a 'wild' mouse-virulent $S$. enteritidis strain, 1203 (Roantree \& Steward, 1965), of typical antigenic composition, i.e. with $O$ antigen $\mathrm{O} 9,12$ and phase-1 $\mathrm{H}$ antigen $g, m$ and no phase-2 flagellar antigen. Mutation his-1461 of R134 falls within the hisEI1659 deletion (P. E. Hartman, personal communication). The cystine requirement of R134 is satisfied by sulphide or thiosulphate but not by sulphite, which indicates its cys mutation is either at cysC or cys $D$ within the cysCDHIJ cluster at 60 units, or at cysG at 72 units (Sanderson \& Hartman, 1978). The gal mutation of R134 did not alter its smooth character, which shows that galE function was not affected. Strain R134 is as penicillin-sensitive and as serum-resistant as its 'wild' ancestor, I203, but, for unknown reasons, of reduced mouse-virulence (intraperitoneal route). The strains used as conjugational donors of O-group B or D (Table 1) were all smooth, serum-resistant and about as penicillin-sensitive as strain R134. Phages P22 and P22h (Wilkinson et al., 1972) were used for transduction. For the phages used to test LPS character ('phage pattern'), see Wilkinson et al. (1972).

Phage and genetic methods. Phage-sensitivity patterns were determined as described by Wilkinson et al. (1972), except that the medium used was Difco nutrient agar, and the stock of smooth-specific phage 9NA had been propagated on a derivative of S. enteritidis I203 instead of an S. typhimurium LT2 subline. Recombinants were tested for sensitivities to phages $\mathrm{P} 22 . c 2,9 \mathrm{NA}, 6 \mathrm{SR}$ and $\mathrm{Br}$ 2. For transduction, phage and broth culture were mixed, to give phage : bacterium ratios of about $1: 1,5: 1$ or $10: 1$, and then centrifuged; after incubation at $37^{\circ} \mathrm{C}$ for 10 min (for smooth strains) or $3 \mathrm{~h}$ (for the part-rough strain, R146) the mixture was centrifuged again and samples of washed cells were plated on selective medium. For conjugational crosses, equal volumes of young broth cultures of donor and recipient were mixed, centrifuged, incubated at $37^{\circ} \mathrm{C}$ for $2 \mathrm{~h}$ and then centrifuged again; samples of washed-cell suspensions were plated on selective media. Transconjugants and transductants were purified by single-colony reisolation on selective medium before testing their phenotype (where appropriate by prong replication from a nutrient agar master plate). Penicillinsensitivity was determined by streaking loopful amounts of broth cultures (about $10^{6}$ cells) on plates of nutrient agar with penicillin $\mathrm{G}\left(5,10,15\right.$ or 20 units $\left.^{-1}\right)$. For tests of sensitivity to the bactericidal effect of normal serum, inocula of about $0.001 \mathrm{ml}$ of overnight broth cultures were mixed with $0.2 \mathrm{ml}$ of fresh normal human serum (not inactivated), and samples (about $0.001 \mathrm{ml}$ ) of this mixture were streaked on nutrient agar immediately after mixing and again after $2 \mathrm{~h}$ incubation at $37^{\circ} \mathrm{C}$.

To score the $H$ (flagellar antigen) alleles of recombinants from crosses of diphasic donors (S. typhimurium or $S$. abony), they were first prong-replicated to plates of semi-solid medium containing anti-g, $m$ serum (final concentration 1/50) and then recombinants giving spreading growth (i.e. able to express an $\mathrm{H}$ antigen other than that specified by the $H I$ allele of the recipient) were further tested by slide agglutination. The $\mathrm{O}$-antigen character of recombinants was determined by a slide agglutination test, using $\mathrm{O} 4,5,12$ and 09,12 sera at a final dilution of $1 / 20$ in normal saline. Phage patterns of recombinants were inferred from their sensitivity or resistance to two smooth-specific phages, P22.c2 and 9NA, and two rough-specific phages, $6 \mathrm{SR}$ and $\mathrm{Br} 2$. 
Table 1. Principal Salmonella strains used

Strain no. Description*

Origin/reference

I203 S. enteritidis $(09,12)$ : wild-type (prototrophic, smooth, serumres, pen-sen)

R134 S. enteritidis: gal-707 his-1461 cys-1159 (smooth, serum-res, pen-sen)

R146 S. enteritidis: gal-707 his-1461 cys-1159 rfb-968 (part-rough, serum-sen, pen-res)

R147 S. enteritidis: gal-707 his-1461 cys-1159 (smooth, serum-sen, pen-res)

PG189 S. typhimurium LT2 HfrB2 (O1,4,5,12): proA26(P22) $\mathrm{clb}^{+}$tre ${ }^{+}$ (smooth, serum-res, pen-sen)

Roantree \& Steward (1965)

From I203 by EMS $\uparrow-$ induced mutations

Spontaneous mutant of R134, penicillin selection

Spontaneous mutant of R134, penicillin selection

SU418; Sanderson et al. (1972)

SR305 S. typhimurium LT2 HfrA $(\mathrm{O} 4,5,12)$ : his D23 gal-50 (smooth, serum-res, pen-sen)

SW1444 S. abony HfrH1 (O1,4,5,12): aroD851 metA1151 rpsL501 (smooth, SW1391; Mäkelä (1963) serum-res, pen-sen)

SL987 S. enteritidis M178 $\operatorname{trp}$ (F'59 pyrB): (smooth, serum-res, pen-sen)

Mäkelä \& Ziegler (1966)

* For definitions of serum-resistance and sensitivity (serum-res and serum-sen), and penicillin-resistance and sensitivity (pen-res and pen-sen), see Methods; smooth indicates smooth phage pattern; $c l b^{+}$and $t r e^{+}$ indicate increased ability to utilize cellobiose and trehalose, respectively.

$\dagger$ EMS, Ethyl methanesulphonate.

\section{RESULTS}

Isolation and general characterization of penicillin-resistant, serum-sensitive mutants

Mutant R146 was the only serum-sensitive strain of 35 strains picked from penicillinresistant colonies appearing on gradient plates $\left(20\right.$ units $\left.\mathrm{ml}^{-1}\right)$ seeded with about $10^{8}$ bacteria of the parent strain R134. Mutant R147 was the one serum-sensitive strain of 15 tested from a similar selection. As may be seen in Table 2, R146 behaves like a part-rough strain being weakly agglutinated in anti-O9 serum and giving an R-sens phage pattern (not affected by smooth-specific phages but lysed by FO phage and the rough-specific phages 6SR and $\mathrm{Br} 2$ ) which in $S$. typhimurium is characteristic of mutants making complete core LPS without O chains (Wilkinson et al., 1972). Characteristics of a S. typhimurium rfaL transductant with the same phage pattern are included in Table 2. Mutant R147 is like its parent except for its penicillin-resistance and serum-sensitivity.

Analysis by thin-layer chromatography and spectrophotometric estimation of the products of the Dische reaction of LPS extracted from mutant R146 by the hot phenol method (by Dr Bruce Cohn) revealed much reduced amounts of the smooth-specific sugars tyvelose, mannose and rhamnose, compared with the parent strain. O-specific sugars were nearly absent in the supernatant ( $\mathrm{L} 1$ fraction) after ultracentrifugation, indicating that $\mathrm{R} 146$ is not a mutant of the $r f a$ or $r f b T$ class (see Stocker \& Mäkelä, 1971). Its ability to ferment mannose indicates it is not a pmi mutant.

The $r f b$ gene cluster of $S$. typhimurium includes genes for various enzymes concerned in the synthesis of the immediate precursors of the O-specific sugars of the oligosaccharide repeating unit, i.e. TDPrhamnose, CDPabequose and GDPmannose (Nikaido et al., 1967). Table 3 records the activity of these enzymes in extracts of the smooth, serum-resistant $S$. enteritidis parent and of its part-rough mutant R146, as determined by Dr Nikaido. The activities of the extracts of mutant R146 did not differ significantly from those of the smooth parent. Thus, the reduced content of O-specific material in the LPS of strain R146 does not result from inability to synthesize any of the precursors of its O-specific sugar components. 
Table 2. Comparison of pertinent phenotypic characteristics of $S$. enteritidis and S. typhimurium smooth parent strains and their penicillin-resistant derivatives

\begin{tabular}{|c|c|c|c|c|c|}
\hline Strain & $\begin{array}{c}\text { Serum- } \\
\text { sensitivity* }\end{array}$ & $\begin{array}{c}\text { Penicillin } \\
\text { m.i.c. }{ }^{\dagger} \\
\text { (units } \mathrm{ml}^{-1} \text { ) }\end{array}$ & $\begin{array}{l}\text { Deposit } \\
\text { in broth }\end{array}$ & Agglutination & $\begin{array}{l}\text { Phage } \\
\text { pattern }\end{array}$ \\
\hline S. enteritidis & & & & (O9) & \\
\hline R134 & Res & 8 & 0 & +++ & Smooth \\
\hline R146 & Sen & 20 & ++ & + & R-sens \\
\hline R147 & Sen & 16 & 0 & +++ & Smooth \\
\hline S. typhimurium & & & & $(\mathrm{O} 4)$ & \\
\hline SL1515 & Res & 6 & 0 & $++t$ & Smooth \\
\hline SL3749(rfaL) & Sen & 8 & ++ & 0 & R-sens \\
\hline
\end{tabular}

Table 3. Activities of enzymes involved in nucleotide-sugar synthesis; data of Dr H. Nikaido

Enzymes were assayed as described by Nikaido et al. (1967). The results are expressed as percentages of the specific activities found in $S$. typhimurium LT2.

\begin{tabular}{|c|c|c|c|c|c|c|c|c|c|c|c|c|c|}
\hline \multirow[b]{3}{*}{ Strain } & \multirow[b]{3}{*}{$04 / 9$} & \multirow{3}{*}{$\begin{array}{c}\text { Phage } \\
\text { pattern }\end{array}$} & \multicolumn{11}{|c|}{ Enzyme specific activity* } \\
\hline & & & \multirow{2}{*}{$\begin{array}{l}\text { UDPG } \\
\text { PPase } \\
(g a l U)\end{array}$} & \multicolumn{3}{|c|}{ Rha } & \multicolumn{3}{|c|}{ Abeq } & \multicolumn{2}{|c|}{ Man } & \multirow{2}{*}{$\begin{array}{c}\text { GNAC } \\
4\end{array}$} & \multirow{2}{*}{$\begin{array}{c}\text { Man } \\
1(p m i)\end{array}$} \\
\hline & & & & 2 & 1 & 3 & 1 & 2 & 3 & 3 & 2 & & \\
\hline $143 \mathrm{HfrA}$ & O4 & Smooth & 98 & 108 & 124 & 74 & 70 & 23 & $64 a \ddagger$ & 105 & 119 & 93 & 97 \\
\hline 134 & O9 & Smooth & 128 & 45 & 90 & 51 & 116 & 22 & $123 t$ & 70 & 115 & 100 & 64 \\
\hline R146 & 09 & Part-rough & 218 & 37 & 84 & 57 & 135 & 31 & $82 t$ & 72 & 133 & 107 & 75 \\
\hline
\end{tabular}

* Abbreviations for the names of enzymes: UDPG PPase, UDPglucose pyrophosphorylase; Rha-1, TDPglucose pyrophosphorylase; Rha-2, TDPglucose oxidoreductase; Rha-3, TDPrhamnose synthetase; Abeq-1, glucose-1-phosphate cytidylyltransferase; Abeq-2, CDPglucose oxidoreductase; Abeq-3, CDPabequose synthetase; Man-1, phosphoglucomutase; Man-2, phosphomannomutase; Man-3, mannose-1phosphate guanylyltransferase; GNAc, UDP- $N$-acetylglucosamine pyrophosphorylase.

$\dagger$ See Table 1 .

In Abeq-3, $a$ and $t$ indicate the synthesis of CDPabequose and CDPtyvelose, respectively.

\section{Genetic analysis of part-rough mutant $\mathrm{R} 146$}

Mutant R146 was used as recipient in crosses with two $S$. typhimurium Hfr strains (PG189 or SR305) or the S. abony Hfr strain SW1444. In the cross recorded in Table 4 the donor was strain PG189, an HfrB2 derivative of S. typhimurium LT2 (Sanderson et al., 1972), which transfers its chromosome clockwise from about 37 units on the recalibrated map (Fig. 1). Of 48 recombinants selected for possession of the donor hisEI+ and recipient pro $^{+}$(Table $4 a$ ), 37 resembled the smooth donor parent in their level of penicillin-sensitivity, resistance to killing by serum, and phage patterns. The 11 other his $^{+}$pro $^{+}$recombinants resembled the recipient parent, $\mathrm{R} 146$, in penicillin-resistance, serum-sensitivity, and phagesensitivity pattern. The co-inheritance of either the three mutant phenotypic traits of R146 or of the corresponding wild-type characters indicates that all three traits resulted from a single mutation. Three of the $37 \mathrm{his}^{+} \mathrm{pro}^{+}$recombinants which had acquired donor smooth character were strongly agglutinated by the anti-O4 serum and not by anti-O 9 serum; the other 45 recombinants were agglutinated only by anti-O9 serum like the recipient parent, R146. No other unselected donor 'marker' was represented in more than one of the 48 recombinants tested. In the same cross (Table $4 b$ ), two of 49 recombinants selected for possession of $\mathrm{cys}^{+}$of the donor and $\mathrm{pro}^{+}$of R146 were donor-like in penicillin-sensitivity, serum-resistance and phage pattern. The rest were recipient-like in those traits.

It appears from these results that the mutation causing the penicillin-resistance, serum- 
Table 4. Frequency of recombinant classes in crosses of $S$. typhimurium PG189 HfrB2 with S. enteritidis R146

The donor was $S$. typhimurium PG189 HfrB2 [LT2 proA(P22) $\mathrm{clb}^{+}$tre $\mathrm{e}^{+} H 1$ (i) $H 2(1,2), \mathrm{O} 1,4,5,12$, serum-resistant, penicillin-sensitive, smooth phage pattern]. The recipient was $S$. enteritidis $\mathrm{R} 146$ [gal hisEI cys $H I(\mathrm{~g}, \mathrm{~m}), \mathrm{O} 9,12$, serum-sensitive, penicillin-resistant, rough phage pattern]. There were negligible numbers of hisEI $I^{+}$or $c y s^{+}$revertants in the $\mathrm{R} 146$ controls and of pro $A^{+}$revertants in the PG189 HfrB2 controls.

\begin{tabular}{|c|c|c|c|c|c|c|c|c|c|c|}
\hline \multirow{3}{*}{ No. } & \multicolumn{7}{|c|}{ Loci, in order transferred: } & \multirow{2}{*}{$\begin{array}{l}\text { Serum- } \\
\text { sensitivity* }\end{array}$} & \multirow{2}{*}{$\begin{array}{l}\text { Penicillin- } \\
\text { sensitivity* }\end{array}$} & \multirow{2}{*}{$\begin{array}{l}\text { Phage } \\
\text { pattern } †\end{array}$} \\
\hline & $H I$ & hisEI & O4/9 & $H 2$ & cys & $\operatorname{proA}$ & gal & & & \\
\hline & \multicolumn{10}{|c|}{ (a) Selected as his $^{+}$pro ${ }^{+}$, i.e. for donor $h i s E I^{+}$and recipient pro $A^{+}$} \\
\hline 34 & $\mathrm{~g}, \mathrm{~m}$ & + & O9 & - & - & + & - & Res & Sen & Smooth \\
\hline 11 & $\mathrm{~g}, \mathrm{~m}$ & + & 09 & - & - & + & - & Sen & Res & Rough \\
\hline 2 & $\mathrm{~g}, \mathrm{~m}$ & + & O4 & - & - & + & - & Res & Sen & Smooth \\
\hline 1 & $\mathrm{i}$ & + & $\mathrm{O} 4$ & 1,2 & - & + & - & Res & Sen & Smooth \\
\hline $\begin{array}{l}\text { Total with } \\
\text { donor allele }\end{array}$ & 1 & 48 & 3 & 1 & 0 & 0 & 0 & 37 & 37 & 37 \\
\hline \multicolumn{11}{|c|}{ (b) Selected as $c y s^{+}$pro $^{+}$, i.e. for donor $c y s^{+}$and recipient $p r o A^{+}$} \\
\hline 47 & $\mathrm{~g}, \mathrm{~m}$ & - & O9 & - & + & + & - & Sen & Res & Rough \\
\hline 1 & $\mathrm{~g}, \mathrm{~m}$ & - & O9 & - & + & + & - & Res & Sen & Smooth \\
\hline 1 & $\mathrm{~g}, \mathrm{~m}$ & - & O4 & - & + & $t$ & - & Res & Sen & Smooth \\
\hline $\begin{array}{l}\text { Total with } \\
\text { donor allele }\end{array}$ & 0 & 0 & 1 & 0 & 49 & 0 & 0 & 2 & 2 & 2 \\
\hline
\end{tabular}

(c) Selected as $\mathrm{his}^{+} \mathrm{cys}^{+}$pro $^{+}$, i.e. for donor hisEI $\mathrm{I}^{+}$and $\mathrm{cys}^{+}$and recipient proA $\mathrm{A}^{+}$

\begin{tabular}{|c|c|c|c|c|c|c|c|c|c|c|}
\hline 8 & $\mathrm{~g}, \mathrm{~m}$ & + & O9 & - & + & + & - & Sen & Res & Rough \\
\hline 7 & $\mathrm{~g}, \mathrm{~m}$ & + & $\mathrm{O} 4$ & - & + & + & - & Res & Sen & Smooth \\
\hline 4 & $\mathrm{~g}, \mathrm{~m}$ & + & 09 & - & + & + & - & Res & Sen & Smooth \\
\hline 2 & $\mathrm{~g}, \mathrm{~m}$ & + & $\mathrm{O} 4$ & - & + & + & - & Sen & Res & Rough \\
\hline 1 & $\mathrm{i}$ & + & $\mathrm{O} 4$ & - & + & + & - & Sen & Res & Rough \\
\hline 1 & $\mathrm{i}$ & + & O4 & - & + & + & + & Res & Sen & Smooth \\
\hline $\begin{array}{l}\text { tal with } \\
\text { for allele }\end{array}$ & 2 & 23 & 11 & 0 & 23 & 0 & 1 & 12 & 12 & 12 \\
\hline
\end{tabular}

* Res, Resistant; Sen, sensitive.

+ Smooth phage pattern indicates sensitivity to phages P22.c2 and 9NA and resistance to phages 6SR and $\mathrm{Br} 2$ (the donor, HfrB2, was resistant to $\mathrm{P} 22$. 22 because of lysogeny by phage P22). Rough phage pattern indicates sensitivity to phages $6 \mathrm{SR}$ and $\mathrm{Br} 2$ and resistance to phages $\mathrm{P} 22 . c 2$ and $9 \mathrm{NA}$ like the recipient.

sensitivity and rough phage-sensitivity of R146 is closely linked to hisEI, and closer to it than is the part of the $r f b$ gene cluster which determines $\mathrm{O} 4$ or $\mathrm{O} 9$ serological character. Both its phenotype and this result suggest that the mutation of R146 is within the $r f b$ gene cluster (and we therefore assign it mutation number $r f b-968$ ). On this interpretation the gene order is his-rfb-968-O4/9, where O4/9 indicates the part(s) of the $r f b$ gene cluster which determine the serological character of the O-repeat unit, O4 or O9.

Mutant R146 was crossed with two other smooth group B Hfr strains: SW1444, which is $S$. abony HfrH1, and SR305, which is an HfrA derivative of $S$. typhimurium strain LT2 (Table 1). The results of selection for donor hisEI ${ }^{+}$were generally similar to those in the cross with the HfrB2 donor. Table 5 summarizes the distribution of part-rough versus smooth character and of $\mathrm{O}$-antigenic character in recombinants selected as hisEI+ (and also includes a summary of the results in the $\mathrm{HfrB} 2$ cross). Most recombinants resembled R146 in penicillin-resistance, serum-sensitivity and phage pattern, or instead resembled the smooth donor in all three respects. In both the HfrHl and the HfrA crosses, the relative frequency of hisEI+ recombinants with the donor smooth character or with both the smooth character and $\mathrm{O} 4$ character of the donor indicated the gene order: his-rfb-968-rfb(4/9). However, the closeness of linkage of $r f b(4 / 9)$ with his was different in the $S$. abony HfrHl 


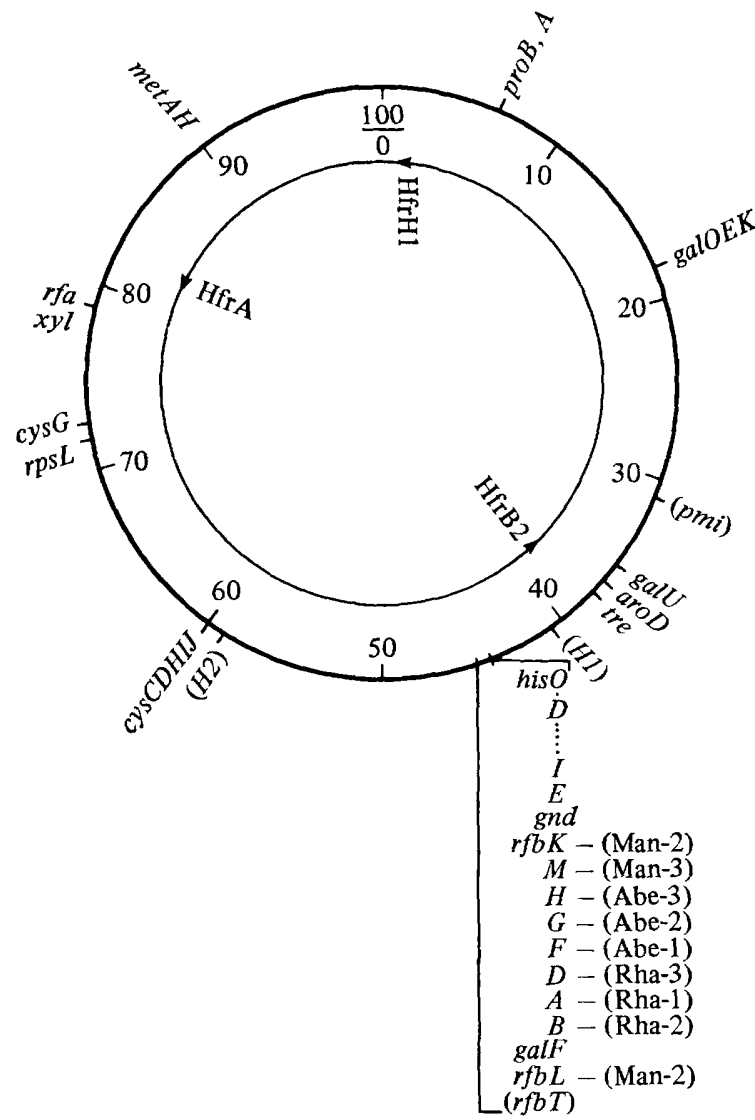

Fig. 1. The linkage map of Salmonella typhimurium. Map positions of standard loci, expressed in units according to Sanderson \& Hartman (1978). Points of origin of Hfr strains are indicated as are the map positions of loci concerned with the biosynthesis of LPS. The relative order of loci shown within parentheses is unknown.

Table 5. $O$ antigen and serum-sensitivity (and correlated characters) of his ${ }^{+}$recombinants from conjugational crosses with $S$. enteritidis $\mathrm{R} 146$ as recipient

The donor strains were $S$. typhimurium HfrA and HfrB2 and $S$. abony $\mathrm{HfrH} 1[\mathrm{O} 4,5,12$ or O1,4,5,12, serum-resistant, penicillin-sensitive, smooth phage pattern]. The recipient was $S$. enteritidis R146 [gal hisEI cys rfb-968 HI(g,m), O9,12, serum-sensitive, penicillin-resistant, rough phage pattern].

\begin{tabular}{|c|c|c|c|c|c|c|c|}
\hline \multicolumn{3}{|c|}{ Donor } & \multicolumn{5}{|c|}{ No. of $h i s^{+}$recombinants in class } \\
\hline $\begin{array}{l}\text { Strain } \\
\text { no. }\end{array}$ & $\begin{array}{c}\text { Contra-selected } \\
\text { gene }\end{array}$ & $\begin{array}{l}\text { Selected } \\
\text { gene }\end{array}$ & Total & $\begin{array}{l}\text { O9, serum- } \\
\text { resistant }\end{array}$ & $\begin{array}{l}\text { O9, serum } \\
\text { sensitive }\end{array}$ & $\begin{array}{l}\text { O4, serum } \\
\text { resistant }\end{array}$ & $\begin{array}{l}\text { O4, serum- } \\
\text { sensitive }\end{array}$ \\
\hline $\begin{array}{l}\text { PG189 } \\
\text { HfrB2 }\end{array}$ & $\begin{array}{l}\text { proA } \\
\text { proA }\end{array}$ & $\begin{array}{l}\text { hisEI+ } \\
\text { hisEI } E I^{+} \text {cys } C^{+}\end{array}$ & $\begin{array}{l}48 \\
23\end{array}$ & $\begin{array}{r}34 \\
4\end{array}$ & $\begin{array}{r}11 \\
8\end{array}$ & $\begin{array}{l}3 \\
8\end{array}$ & $\begin{array}{l}0 \\
3\end{array}$ \\
\hline $\begin{array}{r}\text { SW1444 } \\
\text { HfrH1 }\end{array}$ & $\begin{array}{l}\text { met } A \\
\operatorname{aroD} D\end{array}$ & $\begin{array}{l}\text { hisEI+ } \\
\text { hisEI }\end{array}$ & $\begin{array}{l}25 \\
25\end{array}$ & $\begin{array}{l}4 \\
5\end{array}$ & $\begin{array}{l}6 \\
5\end{array}$ & $\begin{array}{l}15 \\
14\end{array}$ & $\begin{array}{l}0 \\
1\end{array}$ \\
\hline $\begin{array}{r}\text { SR305 H } \\
\text { (2 cros }\end{array}$ & rA & hisEI+ & $136^{*}$ & 54 & 68 & 4 & 1 \\
\hline
\end{tabular}

* These 136 included nine exceptional recombinants. Four were inagglutinable in $\mathrm{O} 4$ or $\mathrm{O} 9$ antiserum (three were recipient-like in serum-sensitivity, penicillin-resistance and phage pattern; the other was recipientlike except for a smooth phage pattern). Five had new recombinations of the three correlated characters. Three (two O4, one O9) were recipient-like in serum-sensitivity and phage pattern, but were not as penicillinresistant as the recipient. Two others (one 04 , the other 09 ) were penicillin-sensitive and resistant to rough phages, like the donor, but were serum-sensitive. 
cross (30 of 50 his $^{+}$recombinants with donor O4 character) from that in the two S. typhimurium Hfr crosses (14 of 71 and 8 of $136 \mathrm{his}^{+}$with donor O4 character). The LT2 HfrA strain used (Zinder, 1960; Sanderson et al., 1972) requires histidine because of a mutation at his $D$; recombinants obtained on medium without histidine were therefore selected for retention of his $D^{+}$of the recipient, as well as for acquisition of hisEI $\mathrm{I}^{+}$of the donor. But as the order of the relevant genes (Fig. 1) is known to be his D-hisIE-rfb, selection against donor his $D$ is not expected to affect the representation of $r f b$ genes amongst recombinants acquiring donor hisEI+. Two his ${ }^{+}$recombinants with $\mathrm{O}$ antigen $\mathrm{O} 4$ but retaining the penicillin-resistance, serum-sensitivity and part-rough character of R146 were encountered amongst $186 \mathrm{his}^{+}$recombinants in the crosses with the HfrH1 and HfrA donors; these recombinants and three similar ones in the HfrB2 cross (Table 5) we attribute to quadruple crossover events. The $h i s^{+}$recombinants from the HfrA cross included four which were not agglutinable in $\mathrm{O} 4$ or $\mathrm{O} 9$ serum; three of them were recipient-like in serum-sensitivity, penicillin-resistance and sensitivity to rough phages, the other was recipient-like except for a smooth phage pattern. Another five his ${ }^{+}$recombinants from this cross appeared to have new recombinations of the three correlated characters. Three recombinants (two ${ }_{4}^{+}$, the other $\mathrm{O9}^{+}$) were recipient-like in serum-sensitivity and sensitivity to rough phages but were not as penicillin-resistant as the recipient. Two others (one $\mathrm{O}_{4}^{+}$, the other $\mathrm{O}^{+}$) were penicillin-sensitive and resistant to rough phages, like the donor, but were serum-sensitive. We did not further investigate these recombinants, for instance to determine if the $\mathrm{O}$ inagglutinable strains made complete core or incomplete core LPS. The representation of unselected loci gave no indication as to their origin, perhaps by unequal crossing over within the partly non-homologous $r f b$ clusters, or by coincidental mutation at $r f b$ or some other locus affecting LPS character or serum-sensitivity or penicillin-sensitivity or (improbably, we think) by crossing over between two closely linked mutant loci in R146, for instance one affecting penicillin-sensitivity and the other causing part-rough character, with sensitivity to rough phages and to serum. Completely rough recombinants from $\mathrm{O} 4 \times \mathrm{O} 9$ crosses have been observed but rarely in previous reports (Mäkelä, 1965; Johnson et al., 1965; Nikaido et al., 1966). Part-rough recombinants would probably have been overlooked in those studies.

The whole of the $r f b$ gene cluster of $S$. typhimurium can be cotransduced with the his operon by phage P22, which, however, is smooth-specific and inactive on R146. The agglutinability of mutant R146 by anti-O9 serum and the presence of small amounts of O-specific sugars in its LPS showed that it synthesizes some 'smooth' LPS side-chains and suggested that it might be susceptible to P22-mediated transduction, despite its resistance to lysis by this phage (cf. Gemski \& Stocker, 1967). Phage P22 propagated on strain I203, the $S$. enteritidis wild-type ( is $^{+}$, penicillin-sensitive, serum-resistant, smooth phage pattern) ancestor of R146, evoked $h i s^{+}$transductants, at a frequency of about 1 per $10^{8}$ plaqueforming units, from strain R134, the smooth his immediate parent of mutant R146. The same lysate also evoked $h i^{+}$transductants from R 146, but the yield per plaque-forming unit was about fivefold lower. A total of $40 \mathrm{his}^{+}$transductants evoked from R146 by either this P22 lysate or by a P22h lysate of the wild-type strain I203 were tested; 32 resembled the recipient, $\mathrm{R} 146$, in their penicillin-resistance, serum-sensitivity and rough phage pattern but eight were donor-like in all these three characters (except that they were unaffected by phage P22 . 2 , probably because they had become P22-lysogenic, since they were sensitive to $9 \mathrm{NA}$, the other O-specific phage used).

\section{Genetic analysis of smooth, penicillin-resistant mutant $\mathrm{R} 147$}

This mutant differed from its smooth parent, R134, only in being penicillin-resistant and serum-sensitive (Table 2). Thin-layer chromatography of a hydrolysate of its LPS showed about the same amount of $\mathrm{O}$-specific sugars as the corresponding materials from the parent strain (B. Cohn, personal communication). 
Several $\mathrm{Hfr}$ or $\mathrm{F}^{\prime}$ crosses were made with the object of mapping the mutation causing serum-sensitivity and penicillin-resistance (without loss of smooth character) in mutant R147 (details of crosses not shown). In crosses with $S$. abony $\mathrm{HfrH} 1$ as donor, 36 of 100 recombinants selected for possession of donor hisEI+ and recipient $\operatorname{aroD} \mathrm{D}^{+}$of $\mathrm{metA}^{+}$had antigen $\mathrm{O} 4$, like the donor; 33 of these 36 were recipient-like in serum-sensitivity and penicillin-resistance. This strongly indicates that the relevant mutation of R147, unlike the part-rough mutation of $\mathrm{R} 146$, is not located between $r f b(\mathrm{O} 4 / 9)$ and hisEI. Only two of the 100 his $E^{+}$recombinants from these selections were donor-like (wild-type) in both their resistance to serum and their sensitivity to penicillin and these two were amongst the only four recombinants which had the donor $\mathrm{gal}^{+}$allele. The $\mathrm{HfrH} 1$ donor was crossed to R147 and selection was made for donor $\mathrm{gal}^{+}$and recipient $\mathrm{metA}^{+}$; only one of $100 \mathrm{gal}^{+} \mathrm{metA}^{+}$ recombinants was donor-like in penicillin-sensitivity and serum-resistance, which makes it unlikely that the mutation of R147 is closely linked to $\mathrm{gal}$. The only conclusions that could be drawn from the crosses of R147 with the HfrH1 donor were that the mutation of R147 was not between his and $r f b$, and not closely linked to hisEI, gal or cys, the loci used as selected donor markers.

In crosses of a $x y l$ mutant of R147 (the $x y l$ mutation was obtained following ethyl methanesulphonate mutagenesis) with the $S$. enteritidis $F^{\prime}$ strain, SL987, 39 of 51 recombinants selected for possession of the donor cys ${ }^{+}$or hisEI $I^{+}$possessed all three of the donor characters, $\left(\right.$ his EI ${ }^{+}, \mathrm{cys}^{+}$and $\left.x y l^{+}\right)$and 35 of these 39 recombinants were donor-like in serum and penicillin character. However, no close linkage of the serum/penicillin character with any of these loci was apparent in this or the other crosses made. This suggests that the mutation of R147 is probably located in the his-cys-xyl segment, i.e. between unit 44 and unit 78 in the current version of the $S$. typhimurium linkage map (Sanderson \& Hartman, 1978), but gives no indication as to its position within that segment.

\section{DISCUSSION}

As mutant R146 was isolated by a single cycle of selection for penicillin-resistance and its three characteristic properties, penicillin-resistance, serum-sensitivity and part-rough character, almost always segregated together in conjugational crosses, it is reasonable to infer that all three properties result from a single mutation. The five recombinants with non-parental combinations of the three correlated characters encountered amongst 136 his $^{+}$recombinants in the $\mathrm{HfrA} \times \mathrm{R} 146$ cross (Table 5) casts some doubt on the hypothesis that the three altered characters of R146 all result from a single mutation. Fuller examination of these five recombinants might have shown whether their exceptional combinations resulted from coincidental mutations affecting LPS character, serum-sensitivity or penicillinsensitivity, or from crossing over between closely linked mutated genes in R146, for instance one causing part-rough character (sensitivity to rough phages and to serum) and the other causing penicillin resistance - but we think this last an unlikely hypothesis. The results of conjugational crosses of 'smooth' donors of group B (antigen O4, abequose as the dideoxyhexose of the O-repeat unit) to R146 as recipient (Table 5) and P22-mediated transductional crosses with the wild-type $S$. enteritidis ancestor of R146 as donor and R146 as recipient clearly show that the mutation of R146 is closely linked to hisEI and to $r f b$, or, more precisely, to the part(s) of the $r f b$ gene cluster which determine $\mathrm{O} 4$ or O9 serological character, that is abequose or tyvelose as the dideoxyhexose branch of the O-repeat unit. On this interpretation the five recombinants which had antigen $\mathrm{O} 4$ from the donor but retained recipient penicillin-resistance, etc. resulted from quadruple crossover events, a class expected to be rare. The phenotype of these $\mathrm{O}^{+}$part-rough recombinants shows that the $r f b-968$ mutation of R146 causes part-rough phenotype even when the O-specific material made contains abequose instead of tyvelose; it is therefore unlikely that the R146 mutation affects the gene for an enzyme which is specific for tyvelose, such as the (postulated) enzyme for 
transfer of this dideoxyhexose from CDPtyvelose to the trisaccharide backbone of the newly formed repeat unit.

In $S$. typhimurium the enzyme which converts CDP-4-keto-6-deoxyglucose to CDPabequose is determined by gene $r f b H$, whose position in relation to other mapped genes within the $r f b$ cluster (Table 3, Fig. 1) is known from tests of enzymic activity of strains with deletions extending into the cluster from the side nearest his (Nikaido et al., 1967). It seems reasonable to assume that the enzyme which in $S$. enteritidis converts CDP-4-keto-6deoxyglucose to CDPtyvelose (CDPtyvelose synthetase) is specified by a corresponding ' $r f b H$ ' gene. If so, the segregation of $\mathrm{O}$-antigen character and of 'part-rough' character in recombinants selected for possession of donor his ${ }^{+}$indicates that the $r f b-968$ mutation of R146 lies between his and $r f b H$ (Fig. 1) specifying the dideoxyhexose of the repeat units. Since other possible mutations have been eliminated (Table 3), we infer that the $r f b-968$ mutation of R146 affects a glycosyl-transferring enzyme needed for the assembly of the repeating unit. Since the part-rough character was present in $\mathrm{O} 4$ as well as $\mathrm{O} 9$ recombinants it is unlikely that $r f b-968$ affects the tyvelose-transferase gene. Thus, one of the other three transferases (galactosyl-, mannosyl- or rhamnosyl-transferases) involved in the assembly of the O-repeat units of group B and D Salmonella must be affected. These are known to be part of the $r f b$ gene cluster but their position in relation to the mapped genes for biosynthetic enzymes is not known, except for some unpublished evidence as to the location of the gene for the galactosyl-transferring enzyme (Nikaido et al., 1967; H. Nikaido, personal communication). The results shown in Table 4 indicate that at least one of these three transferase genes is on the his side of gene $r f b H$, the enzyme catalysing the last step in the synthesis of CDPabequose (in $S$. typhimurium) and, we assume, a corresponding gene for the enzyme synthesizing CDPtyvelose in $S$. enteritidis.

In Salmonella and related genera, rough mutants, of all types tested, are readily killed by exposure to complement-containing normal serum (Nelson \& Roantree, 1967), and selection for penicillin-resistance yields mutants some of which are 'rough', as discussed in the Introduction. Thus, the salient features of the phenotype of R146 are all explicable by the postulated partial defect of a transferase function needed for assembly of the O-repeat unit. Why the absence of $O$ chains, by itself or in consequence of the absence of one or more of the outer units of the LPS core chain (Roantree et al., 1977), should cause somewhat reduced sensitivity to penicillin remains to be discovered. Mutation of $r f b-968$ of mutant R146 should result in production of complete rough core LPS with only a few O chains, thus resembling that of $r f a L$ strains. Mutant R146 shows increased resistance to novobiocin and cephalothin as well as to penicillin, similar to that previously shown in $r f a L$ transductants (Roantree et al., 1977). The $r f a$ mutations in Salmonella conferring increased resistance to penicillin are presumably analogous to the $l p c$ (lps) mutations conferring ampicillinresistance in Escherichia coli $\mathrm{K} 12$ (Eriksson-Grennberg et al., 1971). In E. coli $\mathrm{K} 12$ increased penicillin-resistance caused by mutation at the his-linked region corresponding to $r f b$ of $S$. typhimurium would not have been detected since strain $\mathrm{K} 12$ is already rough, but probably would be detected if rough mutants of smooth $E$. coli were tested.

This work was supported in part by the Petricciani Fund, U.S. Public Health Service research grants AI 02755 and AI 07168, and training grant AI 00082 from the National Institute of Allergy and Infectious Diseases. The paper is submitted by D. E. Myers in partial fulfilment of the Ph.D. requirement, Department of Medical Microbiology, Stanford University. 


\section{REFERENCES}

Davis, B. D. \& Mingloli, E. S. (1950). Mutants of Escherichia coli requiring methionine or vitamin B12. Journal of Bacteriology 60, 17-28.

Eriksson-GrennberG, K. G., Nordström, K. \& ENGLUND, P. (1971). Resistance of Escherichia coli to penicillins. IX. Genetics and physiology of class II ampicillin-resistant mutants that are galactose negative or are sensitive to bacteriophage C21 or both. Journal of Bacteriology 108, 1210-1223.

GemSki, P., JR \& Stocker, B. A. D. (1967). Transduction by bacteriophage $\mathbf{P} 22$ in nonsmooth mutants of Salmonella typhimurium. Journal of Bacteriology 93, 1588-1597.

Johnson, E. M., Krauskopf, B. \& Baron, L. S. (1965). Genetic mapping of $\mathrm{Vi}$ and somatic antigenic determinants in Salmonella. Journal of Bacteriology 90, 302-308.

MÄKELÄ, P. H. (1963). Hfr males in Salmonella abony. Genetics 48, 423-429.

MÄKELÄ, P. H. (1965). Inheritance of the O antigens of Salmonella groups B and D. Journal of General Microbiology 41, 57-65.

MÄKeLÄ, P. H. \& ZIEGLER, L. (1966). An F' episome of Salmonella abony. Acta pathologica et microbiologica scandinavica 67, 547-554.

Michael, J. G. \& Braun, W. (1958). Relationships between bacterial resistance to serum and penicillin. Proceedings of the Society for Experimental Biology and Medicine 97, 104-107.

Nelson, B. W. \& Roantree, R. J. (1967). Analyses of lipopolysaccharides extracted from penicillinresistant, serum-sensitive Salmonella mutants. Journal of General Microbiology 48, 179-188.

Nikaido, H., Nikaido, K. \& Mäkelä, P. H. (1966). Genetic determination of enzymes synthesizing $\mathrm{O}$-specific sugars of Salmonella lipopolysaccharides. Journal of Bacteriology 91, 1126-1135.
Nikaido, H., Levinthal, M., Nikaido, K. \& NiKANE, K. (1967). Extended deletions in the histidine-rough $\mathrm{B}$ region of the Salmonella chromosome. Proceedings of the National Academy of Sciences of the United States of America 57, 1825-1832.

Roantree, R. J. \& Steward, J. P. (1965). Mutations to penicillin-resistance in the Enterobacteriaceae that affect sensitivity to serum and virulence for the mouse. Journal of Bacteriology 89, 630-639.

Roantree, R. J., Kuo, T.-T. \& MacPhee, D. G. (1977). The effect of defined lipopolysaccharide core defects upon antibiotic resistances of Salmonella typhimurium. Journal of General Microbiology 103, 223-234.

Sanderson, K. E. \& Hartman, P. E. (1978). Linkage map of Salmonella typhimurium, edition V. Microbiological Reviews 42, 471-519.

SANDERSON, K. E., Ross, H., Ziegler, L. \& MäKELÄ, P. H. (1972). $\mathrm{F}^{+}$, Hfr, and $\mathrm{F}^{\prime}$ strains of Salmonella typhimurium and Salmonella abony. Bacteriological Reviews 36, 608-637.

StOCKer, B. A. D. \& MÄKelä, P. H. (1971). Genetic aspects of biosynthesis and structure of Salmonella lipopolysaccharide. In Microbial Toxins, vol. 4, pp. 369-438. Edited by G. Weinbaum, S. Kadis \& S. J. Ajl. London: Academic Press.

WestPhal, O., Lüderitz, O. \& Bister, F. (1952). Über die Extraktion von Bakterien mit Phenol/ Wasser. Zeitschrift für Naturforschung 7b, 148-155. Wilkinson, R. G., Gemski, P., JR \& Stocker, B. A. D. (1972). Non-smooth mutants of Salmonella typhimurium: differentiation by phage sensitivity and genetic mapping. Journal of General Microbiology 70, 527-554.

Zinder, N. D. (1960). Sexuality and mating in Salmonella. Science 131, 924-926. 